\title{
Nature as an answer
}

\author{
Daniel Edgardo Vedoya ${ }^{1, *}$ \\ ${ }^{1}$ Doctor of Art, Architect, Full Professor at the Faculty of Architecture and Urbanism of the National University of the Northeast \\ (Argentine Republic)
}

\begin{abstract}
I present here a brief summary of the actions that we have initiated in the ITDAHu (Institute of Technological Research for the Environmental Design of Human Habitat), which I direct in the Faculty of Architecture and Urbanism of the National University of the Northeast (in the Argentina Republic), in the search for sustainable design patterns. We see it as appropriate to focus our attention on nature, which has continued through centuries of history and evolution to solve its own problems effectively and efficiently.
\end{abstract}

\section{Introduction}

"If nature is the answer, what was the question?" The phrase belongs to Jorge Wagensberg (2002), $\mathrm{PhD}$ in Physics, Professor at the University of Barcelona in "Theory of Irreversible Processes" [1].

I selected it to title my presentation considering that it summarizes to a large extent the accumulation of situations that occur when we study nature, and I came to the conclusion that the answers we find in it are countless and, nevertheless, many of them we have not yet found the questions that gave them origin [2].

Biomimicry helps us understand these answers and teaches us how to use them for our common good [3].

What I am presenting in this article is a brief account of the few actions that we have carried out in these first steps in search of these questions, together with a group of researchers, members of the ITDAHu (Institute of Technological Research for Environmental Design), which I direct in the Faculty of Architecture and Urbanism of the National University of the Northeast, in Argentina.

We started with a Postgraduate Course on "Introduction to Biomimesis Applied to Architecture" held last year at the Faculty of Architecture and Urbanism of the National University of the Northeast in Argentina.

From there, we linked to the Polytechnic of Turin, thanks to the management of Prof. Caterina Mele, for the implementation of a joint project on "Technologies for Sustainable Construction: The Biomimetic Approach. Methods, materials and applications".

Within the framework of this Project, we have carried out Seminars / Workshops, the first one at the Polytechnic of Turin, on May 2, 3 and 4, 2018, on "Application of Biomimetics to the Project of Sustainable Architecture. Method, applications and materials", and the second in the FAU of the UNNE, in Argentina, on June 28, 29 and 30, 2018, on" Biomimicry and Sustainable Project. An approach based on forms, processes and systems".

We are currently linked to the Inter-institutional Inter-University International Network of Biomimicry Studies, based at the Universidad del País Vasco, in Bilbao (Spain).

We study biomimicry studies according to three approaches:

a. Analysis of a real case of biomimetics;

b. Natural solution applicable to the design of an object;

c. Technical problem and resolution thanks to biomimetics.

In each of these approaches, we apply the approach from three axes: forms, systems and processes.

\section{Backgrounds}

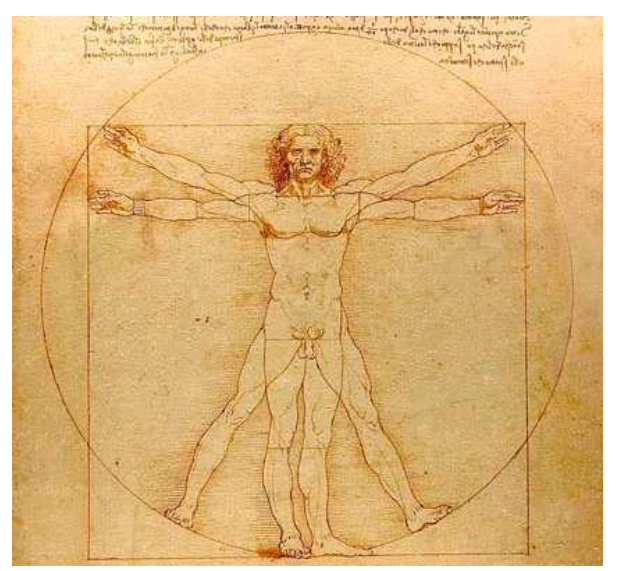

Fig. 1 - The "Vitruvian Man"

Marco Lucio Vitruvio Polion (Rome, 1st Century BC), in his book "De Architectura", better known as "The Ten Books of Architecture", already recommended taking into account the orientation of the buildings, placing

\footnotetext{
Corresponding author: devedoya@gmail.com
} 
them in suitable areas, where there is provision of water, that are sufficiently protected, etc. In his book he also made a study of the proportions of the human body that, centuries later, Leonardo Da Vinci immortalized in the "Vitruvian Man" (Figure 1).

Leonardo of Pisa (Pisa, 1170), known as Fibonacci, brought us closer to nature by using the breeding of rabbits to discover and develop a series that, interestingly enough (an answer whose question has not yet been resolved), is reflected in the proportions and natural sequences of flowers, the organization of the branches of trees, the harmonic growth of living beings. [4]

\section{The Fibonacci series:}

\section{$1,1,2,3,5,8,13,21,34,55,89,144, \ldots$}

Fray Luca Pacioli (Sansepolcro, 1447), averaged the cinquecento reflotates the concept of the number of gold in his book "The Divine Proportion" (1509) [5].

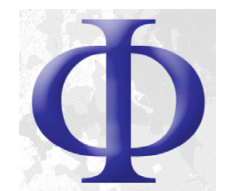

Fig. 2. The Golden number: $1,618033 \ldots$

Half a century later, Galileo Galilei (Pisa, 1564) proposes the thesis that summarizes all these advances: "Mathematics is the alphabet with which God has written the Universe".

Mathematics is present in every corner we study in our journey through nature [6]. The family of numbers is infinitely large. I will only mention some of the most notable, the transcendental numbers $\pi$ y $\boldsymbol{e}$ and the imaginary number $i=\sqrt{ }(-1)$, all of them of great relevance in the universal order. Completing the list of significant numbers, I can't fail to mention the prime numbers.

Not only participate in the universal order. They also give concrete solutions of substance economy, minimum effort, flat and spatial organizations, successfully resolved structures, true works of architecture and engineering, as we will see below.

A few examples will serve to understand what I affirm. I start with a very sympathetic insect, similar to a grasshopper, excessively boisterous and mysterious at the same time: the cicada, known in the northeastern region of Argentina, where I live, as "cicada" (Figure 3).

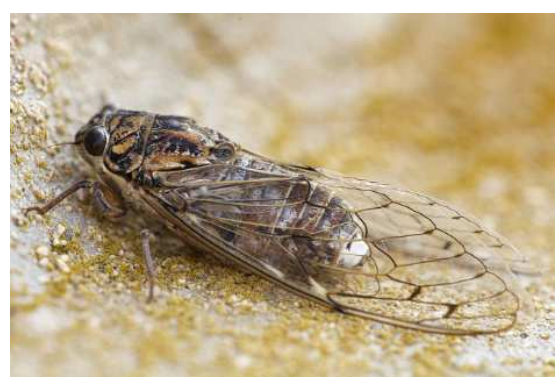

Fig. 3. The cicada
We feel its presence by a deafening shriek that is felt in the whole field, a male calling a female to mate. We see it for the first time attached to the bark of some tree, and then disappear from sight. After spawning, the male dies. The eggs hatch and the larvae fall to the ground and submerge below the surface and stop feeding by absorbing the fluids from the roots of shrubs and trees. There they develop and remain until adulthood.

The curious thing about all this is that there are two species of cicadas, one of which emerges to the surface after being buried for 13 years, and the other after 17 years. If we pay attention, they are two prime numbers. We know that prime numbers are divisible only by themselves and by one, and if we consider all predatory species of cicadas, and all possible life cycles, the coincidence that both are concentrated on the surface of the earth is incalculable. Does this frequency respond to a protection mechanism that is printed in the genetic code of the insect?

Spiders weave a net with the thread that it produces, forming a true tensioned structure. In relation to the size of the spider and the section of the thread, the thread turns out to be 5 times more resistant than the steel. The image below shows how the tensions in the network are distributed until anchored in the supports.

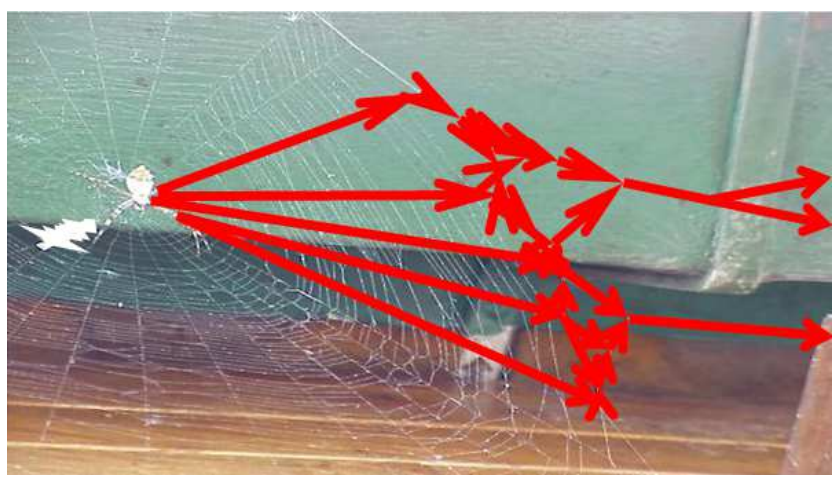

Fig. 4. The spiderweb

Bees offer another situation of unanswered questions give us the bees in the construction of their honeycombs (Figure 5). The cells, which adopt a hexagonal arrangement (according to the RAE), with a concurrence of three cells to a common edge, are arranged according to a plane, with their mouths facing one side [7].

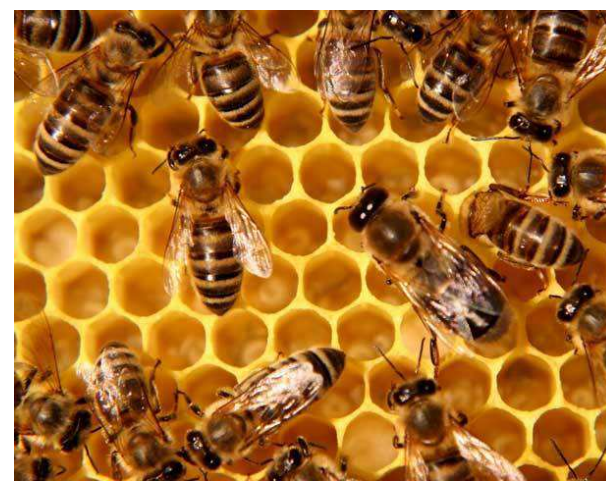

Fig. 5. Honeycomb 
At the rear, another series of cells is arranged, organized in the same way but interspersed so that each edge of a layer coincides with the center of the opposite cell [8]. The connection of one layer with the other is given by a deformation of the bases of the cells according to diamonds that make up a structure avoiding the displacement of one of the layers in relation to the other.

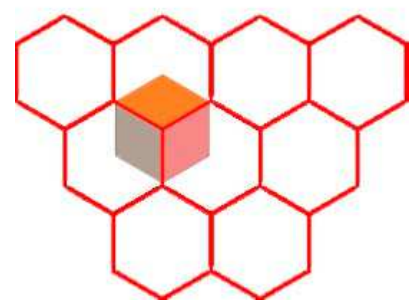

Fig. 6. Internal distribution of bee cells

The amazing thing about this arrangement is that these rhombuses belong to a polyhedron that is known as the rhombic dodecahedron or rhombidodecahedron (Figure 7), composed of twelve regular diamonds that alternate three and four at each vertex, and is one of the five polyhedrons that by adding themselves they massify the space.

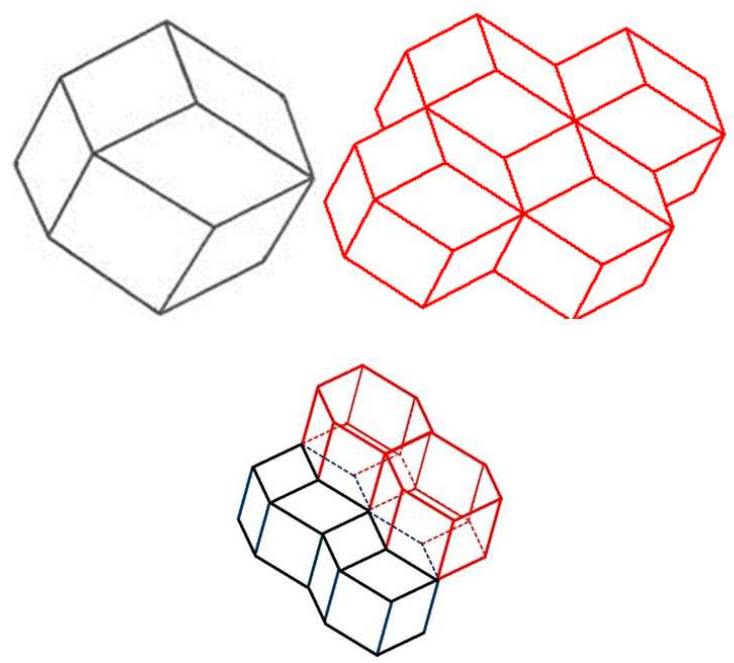

Fig. 7. Rombidodecahedral equipartición

The other four polyhedrons that also massify space are the cube, the triangular and exagonal prisms and the Archimedean polyhedron of Lord Kelvin [9].

Entering the specific field of architecture, African termite mounds have been the inspiration for several buildings. They have the peculiarity of keeping inside a constant temperature of $30^{\circ}$, necessary for the cultivation of the fungus that serves as food, while it is necessary for their survival because it is a very delicate insect. They manage to maintain this constant temperature by means of galleries that allow the entrance of fresh morning air through the lower part of the termite mound, and through ducts that function as chimneys, expelling the hot air through the upper part. The Eastgate building in Harare, Zimbabwe (Figure 8) has been built following this mechanism of galleries, which has achieved a very significant reduction in energy consumption [10].
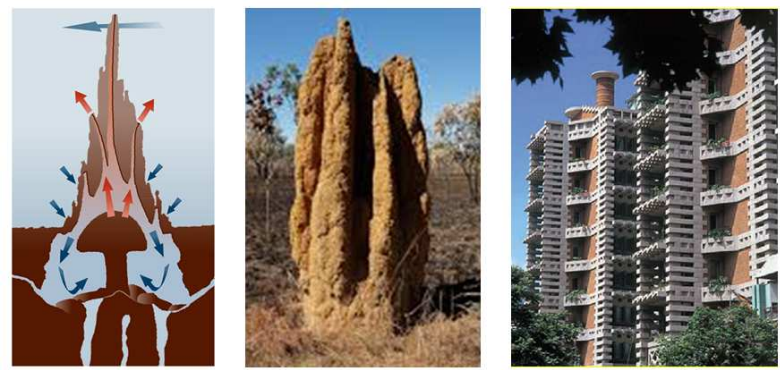

Fig. 8. African termite mounds and the Eastgate building, Harare, Zimbabwe

Something similar has been achieved in Argentina, in hut built according to a design known as "Yobai Culata" (Figure 9), a Guarani term meaning "facing rooms", and presents a game with an intermediate covered patio that allows air circulation, refreshing the rooms.
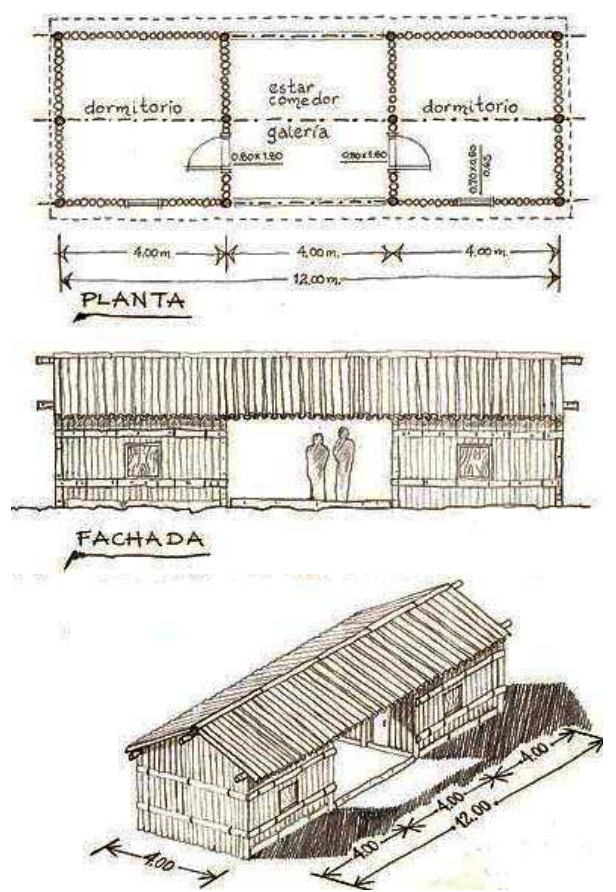

Fig. 9. Yobai Culata

The hornero (furnarius rufus), or Alonsito, is a South American bird of customs worthy of praise. In the first place, once it is even, it remains until the death of both. $\mathrm{He}$ is a true architect, building his nest with mud and straw (Figures 10 and 11). In 1928 it was declared a national bird in the Argentine Republic.

A case no less curious is that of the wasp known as "Camoatí" (Figure 12). Its interior its nest is a closed space, with a single opening at the bottom. It has a system of thermal protection achieved by a series of protuberances protruding from the nest, serving as heatsinks of the interior temperature. 


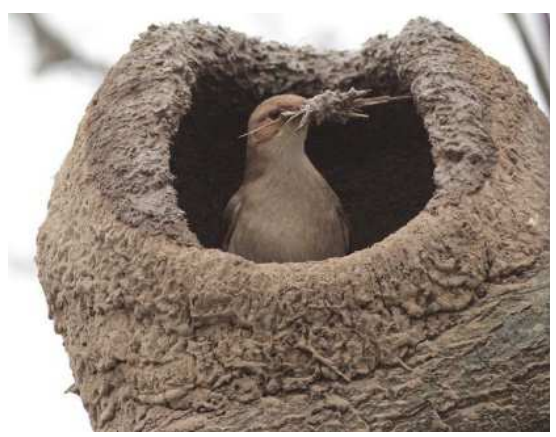

Fig. 10. The hornero nest

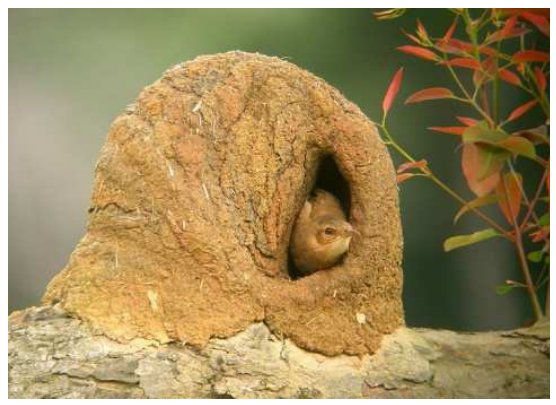

Fig. 11. The hornero nest

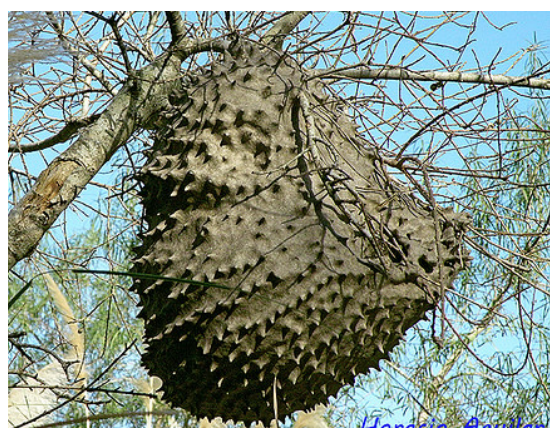

Fig. 12. The camoatí nest

The phenomenon of photosynthesis is carried out inside the leaves of vegetables. There you do not need special tools, or test tubes. Only three components are involved: water, which takes from the ground through its roots and is transported along with various minerals to the most distant leaf, carbon dioxide that absorbs from the outside environment through its stomata, and sunlight. There, the process of photosynthesis ${ }^{1}$ takes place in which water and carbon dioxide combine, releasing oxygen and forming sugar or glucose molecules that serve the food vegetable. Plants are autotrophic, which means that they produce their own food.

A flexible self-repairing concrete is being developed at the University of Michigan, in the USA. Microcracks

\footnotetext{
${ }^{1}$ Photosynthesis: 1 . Water $(\mathrm{H} 2 \mathrm{O})$ : it is extracted from the soil by the roots and transferred by the sap, together with mineral salts; 2. Solar energy: it reaches the chlorophyll contained in the chloroplasts of the leaves; 3. Carbon Dioxide (CO2): the leaf absorbs it from the air through the stomata; 4. Molecules of glucose or sugar (C6H12O6): carbon dioxide combines with water, releasing oxygen; 5 . Large quantities of Oxygen $(\mathrm{O} 2)$ are expelled into the atmosphere through the stomata.
}

that are formed through deformation self-repair with the help of only two components: water and carbon dioxide.

Namibia is a country in southwestern Africa, where one of the oldest deserts and with the highest dunes on the planet is located, with very few rains in the year. There lives an insect known by the name of "Namibian Beetle", which is characterized by collecting the water it needs by causing the fog to condense on its tail, and from there, the drop slides down its shell until it reaches its mouth.

\section{Conclusions}

Learning about behaviour in nature helps us to understand the need to develop actions tending to improve living conditions, avoiding the uncontrolled use and abuse of natural resources. The seven "Rs" of the ecological consumer is a theory providing a synthesis of these actions.

1. Reject: Toxic, non-biodegradable or non-recyclable products should be left out of the shopping list. Even the cleaning of the home can be done in an ecological way, without resorting to industrial products.

2. Reduce: The result of the formula is evident: fewer products, fewer expenses, less exploitation of natural resources, less pollution and waste. Do not stop consuming, but do it with moderation.

3. Reuse: Prolonging the useful life of the goods contributes to domestic saving and to the reduction of the environmental impact. Examples of this practice are cloth bags instead of plastic bags and rechargeable batteries.

4. Recycle: Nature is the best example of recycling, since in it nothing is wasted, everything is reused in one way or another for the benefit of living beings and the environment. Separating waste properly for subsequent recycling is an action with multiple environmental benefits.

5. Redistribute: The environment and humanity can't support indefinitely this unsustainable development and, therefore, we must redistribute consumption in an equitable manner. Products with a lower ecological footprint or based on fair trade principles can reduce these differences.

6. Reclaim: Consumers can and should have an active participation in the activities that influence their daily life. The law covers the possibility of claiming and demanding actions ñthat contribute to improving the environment and the quality of life of citizens.

7. Reflect: Ecological consumers are reflexive and critical, recognize that human beings are part of an interrelated whole: nature. This consists of, for example, choosing goods committed to the environment, using the bicycle as a means of transport, etc.

In 1987, the United Nations entrusted Dr. Gro Harlem Brundtland, along with a group of scientists, with the preparation of a report that later became known as the "Bruntland Report". The thesis was founded on 
sustainable development, in the sense of satisfying the needs of the present without compromising the needs of future generations. This precept involved two concepts, the right and its limits. This includes the rights of inhabitants of the land to make use of natural resources, taking into account the right that also assists future generations in the use of natural resources. It involves making use of natural resources in a rational manner, so as not to exhaust them, thus enabling future generations to make use of them as well. This requires and additional "R": Respect. This respect is a necessary condition for achieving balance within common welfare.

Finally, I consider it essential to add a new "R without which all the above would be meaningless. This "R" has to do with our attitudes and behaviours. It creates a new paradigm, that of Responsibility.

We must act with absolute responsibility in safeguarding strict compliance with all the preceding "R".

\section{References}

1. J. Wagensberg, Si la naturaleza es la respuesta, ¿cuál era la pregunta? (Tusquets Editores S.A., Barcelona, 2002)

2. D. E. Vedoya, La transposición tecnológica. Introducción a la génesis de los procesos tecnológicos (Editorial Académica Española, Saarbrücken, 2014)

3. J. M. Benyus, BIOMIMESIS. Cómo la ciencia innova inspirándose en la naturaleza (Tusquets Editores S.A., Barcelona, 2012).

4. S. Skinner, Geometría sagrada. Descifrando el código (Gaia Editorial, Madrid, 2007).

5. L. Pacioli, La divina proporción, (Editorial Losada, Buenos Aires, 1959).

6. M. du Sautoy, Los misterios de los números. La odisea de las matemáticas en la vida cotidiana (Acantilado Cuaderns Crema, S.A.U., Barcelona, 2009)

7. J. Wagensberg, La rebelión de las formas (Tusquets Editores S.A., Barcelona, 2004)

8. M. du Sautoy, SIMETRÍA, Un viaje por los patrones de la naturaleza (Acantilado Cuaderns Crema, S.A.U., Barcelona, 2009)

9. M. C. Ghyka, Estética de las proporciones en la naturaleza y en las artes, (Editorial Poseidón, Buenos Aires, 1953).

10. P. Pearce, Structure in nature is a strategy for design (The MIT Press, Cambridge, 1979). 